\title{
UNDERSTANDING THE POST 9/11 TRANSATLANTIC SECURITY COMMUNITY ${ }^{19}$
}

\section{Michael R. MacLeod}

Michael MacLeod is a doctoral candidate in Political Science at George Washington University in Washington, DC. He obtained a $B A$ and $M A$ in Political Studies from Queen's University, Kingston, Canada.

\begin{abstract}
Is there an emerging fundamental divide between the United States and Europe in the post 9/11 world? This article examines the transatlantic relationship from a constructivist theoretical approach, emphasizing a security community underlying the North Atlantic region. Constructivists have emphasized how a transnational collective identity develops and builds stable expectations of peaceful relations amongst states, but they have not had much to say about how security communities become de-constructed, i.e. how they break down. To what extent do conflicts in values and norms undermine the collective identity? What I ask here is whether there is a widening difference in the European and American political-strategic cultures that is undermining the security community? My argument is, yes, there is, and the emerging post $9 / 11$ transatlantic security community may look quite different from its predecessor.
\end{abstract}

\footnotetext{
${ }^{19}$ An earlier version of this article was presented at the 2004 Annual Meeting of the American Political Science Association in Chicago, Illinois.
} 


\section{Introduction}

This article addresses the significance of developments in transatlantic foreign and security policy and the challenges the United States and its NATO (North Atlantic Treaty Organization) allies, Europe and Canada are facing. Specifically, it examines the proposition of whether there is an emerging fundamental divide between the United States and Europe in particular, the former entities, and whether 9/11 represents a watershed moment in transatlantic relations. Some argue that while American policies and actions in the aftermath of the terrorist attacks seem to indicate a dramatic divergence with its allies, these were in fact the culmination of trends that began during the 1990s, reflecting changes in American domestic politics but also changing dynamics in Europe as well. ${ }^{20}$ As the other observers admit, there are some serious differences here between the U.S. and its allies, but most of which seem hardly insurmountable nor unprecedented. ${ }^{21}$ Indeed, a former U.S. Ambassador to NATO remarked in 1988 that the alliance "has had about as many crises as birthdays."22

Nevertheless, since the terrorist attacks, the dynamics of the transatlantic relationship have been marked by dramatic developments and the most jarring deterioration since, for example, the Suez Crisis in 1956 or France withdrawing from NATO in 1966; in 2003, it was described as perhaps being in the "gravest crisis" ever. ${ }^{23}$ Although tensions have eased since, the critical question remains: is the transatlantic security community being substantially undermined by both long-term trends and the re-envisaging of American security strategic vision laid out in the National Security Strategy (and its first practical manifestation, the 2003 invasion of Iraq)? To address this question, we need to address the extent to which this community and its collective identity are being threatened, i.e. whether there exists a widening difference in the values and norms underlying the European and American political-strategic cultures? What I argue, in fact, is that a post 9/11 transatlantic security

\footnotetext{
${ }^{20}$ The best known (and well-debated) is Kagan (2003), a pessimistic assessment emphasizing a fundamental divide between the U.S. and Europe based on differing positions of power and views on its uses.

${ }^{21}$ For example, see Jones (2004).

${ }^{22}$ Cited in Hunter (1988), p 210. Sjursen (2004, fn 3) references that a librarian at the Nobel Institute in Norway 'quickly collected nine full pages of relevant titles focusing on conflict or crisis' in the NATO alliance.

23 "Renewing Transatlantic Partnership: How and Why", testimony to the House Committee on International Relations, European Subcommittee, June 11, 2003.
} 
community, which looks quite different from the era before the terrorist attacks in 2001, may be emerging now.

In the following sections, I will first provide a brief overview of North Atlantic relations in the pre-September 11 period, emphasizing the degree to which America and Europe especially had been on a path of divergence and the reasons for this. I shall also offer some explanations of what exactly has changed since the attacks, before concluding with some preliminary thoughts on the potential future of the transatlantic relationship and avenues for further research.

\section{The Transatlantic Security Community to September 11, 2001}

Since the end of the World War II, the Atlantic-based Western industrialized countries have been increasingly bound together economically, socially and militarily. Extensive trade and investment, communication and travel, and formal alliance building through treaties have contributed to the development of a group of democratic nation-states of virtually unsurpassed linkages. Indeed, the original member states did not intend to just establish a formal military (collective defense) alliance in 1949, they also had ambitions of creating an Atlantic 'community. ${ }^{24}$ And they were quickly successful. The intensified social transactions between Western Europe and North America that developed over the next decade led some to assess the region quite positively as representing more than just an alliance: the North Atlantic countries were a "pluralistic security community," a group of like-minded liberal-oriented states in which pacific relations had become the norm and whose democratic values and institutions precluded conflict amongst those states; in such communities, "the keeping of the peace among the participating units was the main political goal overshadowing all others." 25

Despite the potential of Karl Deutsch's security community project, it failed to generate a robust research agenda because of a number of theoretical, conceptual and methodological problems. Moreover, the international relations discipline itself became

\footnotetext{
${ }^{24}$ Sjursen (2004), p 690.

${ }^{25}$ Deutsch (1957), p 31.
} 
dominated by structural realism and rational choice methods; for all these reasons, his approach "was often cited but rarely emulated." ${ }^{26}$ However, in the mid-1990s some scholars began to re-examine the utility of the concept of security communities, especially as a way of explaining the continued existence of NATO in the absence of an external threat, i.e. the Soviet Union. Over the past decade, a number of constructivist interpretations have argued that a Western security community underlies the alliance, holding it together via the binding power of collectively held ideas, which are often more consequential than material or instrumental causes. ${ }^{27}$ Constructivists view the creation of security communities as the formation of "cognitive regions" whose borders manifest the intensity of shared understandings and common identities. The critical element in a constructivist approach is that changes in a state's identity affect its national security interests (and policies); these (re)configurations affect security communities since they reflect, in the first place, the difference (or commonality) of its members' values and identities. ${ }^{28}$ The concept of a security community has been specifically refined to refer to a transnational collective identity in which peaceful relations among its members are not only the norm, but in which military conflict between them is virtually inconceivable. It is, in other words, a grouping whose constituent elements (states and their societies) share many values and are influenced by many common norms such that their citizens and leaders increasingly can be said to have developed a common (or "collective") identity. Moreover, this identity is strong enough even to shape the group's perception of security threats on the basis of distinctions drawn between it and others (the "in" group versus the "out" group).

The constructivist approach thus assumes that security communities are built by states, especial liberal ones, and as such is closely related to, if not an extension of, the democratic peace argument. Accordingly, much of the research in this line has argued that the United States, Canada and Western European countries constructed a common identity over many decades. Specifically, interstate cooperation via NATO "represented a functional institutionalization of the transatlantic security community based on common values and collective identity of liberal democracies," i.e. the community is constituted by shared norms

\footnotetext{
${ }^{26}$ Adler and Barnett (1998), p 9.

27 The collection of works in Adler and Barnett (1998) is considered seminal.

${ }^{28}$ Jepperson, et al (1996), pp 60-63.
} 
and values and understandings amongst its members. ${ }^{29}$ The foremost of these values are said to be human rights, the rule of law and especially democratic governance. However, constructivists have not had much to say about how security communities become deconstructed, i.e. how do they break down? To what extent do conflicts in values and norms undermine the collective identity of the group members? Precisely which values and norms are the most important here? And how do respective domestic institutional arrangements mitigate or accentuate these $?^{30}$ Some argue that a security community might not last long if its members do not share the same basic understandings about the nature of world order, perceived threats and the most appropriate tools of foreign policy. ${ }^{31}$ The literature here is varied and evolving, but holds promise insofar as it directs us towards attempts to understand processes of change in the intersubjective understandings of what it means to identify with others in the community.

How did the transatlantic security community hold up prior to September 11? As was noted, apparent crises were frequent and sometimes accompanied by apocalyptic predictions of the imminent demise of the relationship. Prior to the 1980s, there were a number of disputes and strains, including the aforementioned Suez Canal crisis in 1956 when the United States confronted the United Kingdom and France over their intervention in Egypt, and in 1966 when France withdrew from the military component of NATO over concerns of the loss of sovereignty. Henry Kissinger wrote about the "troubled partnership" in the early 1960s and the Nixon administration declared 1973 the "Year of Europe" to deal with rising tensions. ${ }^{32}$ But it was not until the 1980s that we saw sustained and deep debate over what some called a "widening Atlantic", meaning that "perceptions and interests, as viewed on either side of the ocean, are pulling Europe and America apart."33

Not coincidentally, the 1980s were indeed marked by a seemingly profound difference in political ideologies across the Atlantic. A Republican administration

\footnotetext{
${ }^{29}$ Risse-Kappen (1996), p 398. Note that alliance and community are not the same thing since a security community does not have to lead to an alliance.

${ }^{30}$ Of course when we are speaking of Europe, there are not only national institutions at play but also transEuropean arrangements, notably the EU.

${ }^{31}$ Payne (2004), p 9.

${ }^{32}$ Cited in Wallace (2001).

${ }^{33}$ The term is from the title of the book edited by Pierre (1986), the quote on page 2.
} 
emphasized a dangerous external threat and the need to protect American national interests by a military build-up, which appeared to contrast starkly European social democracy largely focused on forwarding the integration process amongst its states. These differences signaled to some a very real divide taking place and a pessimistic prognostication: "the economic, military and political world of the Atlantic Alliance, in which two generations of Americans and Europeans have grown to adulthood since1945, is visibly crumbling." 34 The crisis then was argued by most to be a function of differing strategic perceptions amongst allies: "[it derives] from the divergent perceptions of alliance, the divergent security needs, and the divergent geopolitical situations of the United States and Europe." ${ }^{35}$ The dispute over the installation of intermediate-range nuclear missiles in Europe in the early 1980s provides no better example of this, and it certainly was not the only one. Nevertheless, even in the midst of these crises, the liberal security community that underlies NATO and marks transatlanticism "set limits on the extent to which the two sides of the Atlantic can drift apart." ${ }^{36}$ Indeed, there seemed to have been a little chance that NATO would dissolve or become anything less than a central component of the wider relationship: "the continued need for the Atlantic Alliance is unchallenged both in terms of values and interests," and the presence of the Soviet threat still shaped the collective identity of the community. ${ }^{37}$

The end of the Cold War and the disappearance of the Soviet threat were predicted by many, especially structural realists, to mean the imminent end of the formal Alliance. ${ }^{38}$ While NATO not only survived but was arguably revived (or reinvented) in the 1990s expanded both in mandate (to out-of-area and non-Article V operations) and membership, the arguments about transatlantic divides persisted. Notwithstanding apparent deeper embedding of transatlantic relations in "dense network of multilateral links" 39 and a "catalog of areas of convergence on important social, cultural, economic and security issues," post-Cold War era did not eliminate some of the deeper differences between the United States and Europe (and to a lesser extent Canada). Indeed, for all the talk of a 'new NATO'

\footnotetext{
${ }^{34}$ Palmer (1988), p 1.

${ }^{35}$ Ravenal (1985), p 11.

${ }^{36}$ Pierre (1986), p 3.

${ }^{37}$ Ibid, p 52.

${ }^{38}$ Waltz (1993) among many.

${ }^{39}$ Wallace (2001), p 17.

${ }^{40}$ Blinken (2001), p 35.
} 
and its success in Kosovo, there was also much discussion of a renewed Euro-bashing in the U.S. and anti-Americanism in Europe, and increasingly divergent security and defense policy interests and perspectives undermining the transatlantic community. While these might seem reminiscent of the crises of the 1980s, there is evidence that the 1990s saw beginnings of a more fundamental divide in what some call the respective American and European "political-strategic cultures", the inclination towards the use of power based upon threat perceptions to norms and values that are the heart of a state's (group's) identity, or what we might call 'deeper forces' at work in transatlantic relations. ${ }^{41}$

In Europe, the post-Cold War era re-oriented identity to focus on Europe rather than the West: "proving that there was a united Europe that took precedence over proving that there was a united West." 42 Rhetorically and institutionally, the formation and evolution of the European Union is an entity that Europeans built to separate themselves from the United States. This facilitated the deepening of a European political-strategic culture based on a) the key values of stability and peace and b) the norms of multilateralism and reluctance to use force as an instrument. Conversely, throughout the 1990s, United States' policy reflected a growing frustration with the European integration enterprise, especially when it came into conflict with the American focus of maintaining its key value of 'freedom of action' and its position of power: the Clinton Administration "followed a consistent strategy in pursuit of a clear objective - the preservation of the United States' pre-eminent global position," or as others have noted, America's real strategy in this time was to pursue a preponderance of power. ${ }^{43}$ Moreover, a 1995 presidential directive announced a principle of pre-emption to counter the growing terrorist threat and their state sponsors. ${ }^{44}$ And while the U.S. seemed committed to multilateralism in the 1990s, it was in large part used to deal with issues that did not touch American vital interests. The U.S. has become increasingly suspicious of multilateral institutions it helped establish since World War II, while the EU had increasingly overcome its ambivalence towards multilateralism, seeking to export its domestic model and policies to wider multilateral forums. ${ }^{45}$

\footnotetext{
${ }^{41} \operatorname{Hopf}(2001), \mathrm{p} 1$.

${ }^{42}$ Kagan (2003), p 13.

43 The quotation is from Mastanduno (1997), p 51. See Leffler (1992) on the 'preponderance of power'.

${ }^{44}$ Cited in Leffler (2004), p 1053.

${ }^{45}$ Croci (2003), p 487.
} 
The above stated highlights why it would be wrong to over-estimate the influence of 9/11 as producing a deep schism in transatlantic relations. It may be that the transatlantic security community has two different 'reference points' informing its collective identity. For many Europeans, November 9, 1989 and the fall of the Berlin Wall was a catalytic framing event that has shaped much of their foreign and security policy. The collapse of the Soviet Union and its hold on Eastern Europe unleashed an earthquake that is still shaking the continent and its institutions. For Europeans, the world of November 9 represents promise and possibilities; it tells them that if they work together, they may be able to take advantage of an historical opportunity to manage the security of their continent for the first time. While the 1990s also clearly showed that such optimism would get bogged down in messy realities of (re)integrating former communist countries and dealing with rising nationalist threats and civil wars, the idea of 'Europe' is a profound motivation that even today still largely sidelines other priorities. Indeed, it may even be less about results than about a deep commitment to the process of reform and integration. ${ }^{46}$ For Americans, on the other hand, the events of 11 September have left 1989 behind as a "bookend to an era of transition to a new and newly dangerous century," a world marked by tragedy and full of new dangers, telling them that the worst is yet to come. ${ }^{47}$

\section{What Changed (or Did Not Change) after September 11, 2001?}

“Americans are fond of saying, 'The world changed on September 11.' But what has changed is America. The extraordinary moral self-righteousness of this Administration is quite surprising and staggering to Europeans." 48

"For everyday, non-political Americans, Europe is simply not a preoccupation one way or the other. It is Canada with castles ... a nice place, but hardly the furnace where our future will be forged." ${ }^{49}$

\footnotetext{
${ }^{46}$ Jones (2004), p 610.

${ }^{47}$ The above is a synopsis of comments by Daniel Hamilton before the House Committee on International Relations, June 11, 2003.

${ }^{48}$ Jacques Rupnik, former aid to Czech President Vaclav Havel, cited in Alterman (2003).

${ }^{49}$ Cited in Zinmeister (2003).
} 
The new Bush administration entered the office in early 2001 and quickly made its mark in establishing a strong tone of, if not outright defiance of multilateralism, then certainly a clear signal that it would subject international institutions (organizations, treaties, rules, norms and laws) even more starkly to U.S. national interests. The substance of this more unilateralist bent reflects long-term trends in America, what some call the deepening of national culture, to one diverse and multi-ethnic, but also a reinforcement of patriotism and more skeptical, if not suspicious, of "non-American" ideas and values. ${ }^{50}$ In terms of international relations, this was reflected by the Bush inclination to experiment with a new concept: that the sheer preeminence of American power could itself be the ordering and taming principle of a disorderly and dangerous world, a power confidently asserted without reliance on structural arrangements that limited America's 'freedom for action.' This was the subtext of the administration's rejection of various international treaties (Kyoto, the ICC, the ABM treaty, the land mine ban) and other conventions. ${ }^{51}$ The sheer provocativeness (to many Europeans - and Canadians) of this approach made for immediate splashy headlines and a fear of yet another transatlantic crisis. ${ }^{52}$

Then came September 11. While the United States initially made an attempt to appeal to international institutions such as NATO and the UN, it should not have come as a surprise to Europeans that the Bush administration utilized a mainly unilateral response in a complex and multidimensional plan against terrorism and their state sponsors, given the first nine months of 2001, as well as the longer trends already noted. Certainly, the attacks made Americans in general more supportive of the unilateralist premise of the administration's foreign policy, and especially more receptive to the doctrine of preemption and prevention that eventually emerged. The source of this support is clear: fear that sprang forth from the violence and depth of the shock experienced on that day by a country that had no recent experience of war and heavy casualties on its own soil. American citizen anxiety and preoccupation with security remain essentially as great as immediately after the terrorist

\footnotetext{
${ }^{50}$ Jones (2004), p 616.

${ }^{51}$ Talbott (2004), p 1004.

${ }^{52}$ See for example Wallace (2001).
} 
attacks. ${ }^{53}$ This fear, in turn, has shaped policy and elevated pre-emption to a new (arguably the highest) degree of importance.

The September 2002 National Security Strategy (the 'Bush Doctrine') expresses some of the above and articulates the key elements that comprise the American political-strategic culture, i.e. the inclination to use force to deal with threats to values and norms. The terrorist attacks confronted the United States with a threat to its core value, freedom, and convinced the Bush administration that international terrorism (terrorist and state sponsors) and the threat of weapons of mass destruction were the instruments of that threat. It is true that in many respects, the new Doctrine is more firmly rooted in the past than most people realize; as noted above, its focus on pursuing a preponderance of power (via military superiority) and pre-emptive unilateralism. Moreover, some argue that the NSS synthesizes Wilsonian internationalism and the Rooseveltian Rough Rider spirit, i.e. making the world safe for democracy with a very big stick. ${ }^{54}$

While some argue that the Bush Doctrine has a more complex and even conflicting agenda than it may appear on the surface, entrenching American hegemonic power and justifying unilateral pre-emption are nevertheless its overarching principles. ${ }^{55}$ The war on Iraq was of course the first manifestation of the Doctrine in action, with the U.S. having equated (constructed?) the regime there as a part of the threat on America from international terrorism. The emphasis on Iraqi regime change highlighted to many the extent to which American and European (and arguably Canadian) political-strategic cultures had drifted apart. Despite a lack of clear unity in Europe on the invasion of Iraq, the gap between it and the U.S. on the proper use of military power was dramatic and unprecedented. Arguably, many in Europe and elsewhere do not understand the America they think they know so well, and the profound impact of $9 / 11$ on the U.S. and American national security policy. ${ }^{56}$ Hence, when America's NATO partners were told that institutions that did not fully support the war on terrorism (including Iraq) would be sidelined and replaced with 'coalitions of the

\footnotetext{
${ }^{53}$ Hoffmann (2003), p 1032.

${ }^{54}$ Talbott (2003), p 1040.

${ }^{55}$ See for example Leffler (2004) for an argument about the multi-faceted and paradoxical dimensions of the doctrine.

${ }^{56}$ Harries (2002).
} 
willing,' there seemed to be genuine shock in some quarters that the U.S. would go that far. ${ }^{57}$ Likewise, the lack of unqualified moral and political support in the period of failed diplomacy before the Iraq war from European (and Canadian) members of the transatlantic community was viewed in America both as particularly damaging and as an indication of how divergent American values were from these countries.

For many Europeans, fighting the war on terrorism was from the beginning more about dealing with root causes, than dealing with symptoms and legitimizing intervention through the United Nations Security Council. Moreover, as noted earlier, integrating Europe economically, socially and militarily has remained a central focus, notwithstanding continuing difficulties over the development of the European constitution. The Kagan thesis on the American-European divide, while rightly criticized for having a simplistic treatment of power, does point out the construction of Europe as driving the continent since the end of the Cold War, as was noted above:

"Post-Cold war Europe agreed that the issue became "the West." For Europeans, the issue became "Europe" ... the present gap today between the United States and Europe may be traced in part to Europe's decision to establish itself as a single entity apart from the United States." 58

The war on terrorism and especially the war on Iraq have arguably accelerated the expansion and integration of Europe. For example, prior to $9 / 11$, negotiations had stalled over the entry of some East European countries into the European Union but advanced quickly in 2002, despite the fact that several states in 'new' Europe were participants in the coalition against Iraq. Moreover, even amongst the latter it did not take long for there to be evidence of "Iraq fatigue" and indication that these countries wanted to re-focus back on the 'Europe project. ${ }^{, 59}$ The U.S. did not help the European governments which participated in the coalition by the criticisms voiced in America over the Spanish electorate's response to the terrorist attacks there in March, 2004, calling it appeasement and a victory for terrorism.

\footnotetext{
${ }^{57}$ Hoffmann (2003), p 1033.

${ }^{58}$ Kagan (2003), p 84 passim.

${ }^{59}$ The Economist, July 10, 2004.
} 
Since then, there appears to have developed a relative peace amongst the U.S. and many European countries, broken only by the occasional irritant such as the revelations that the CIA has secret prisons across Eastern Europe for interrogating suspected terrorists. ${ }^{60}$

\section{Conclusion}

From the perspective of a Canadian who has studied and taught in the United States and has also traveled extensively in Europe, transatlantic relations have been fascinating to observe. On the one hand, there is an enduring formal alliance structure, NATO, which both reflects common values and interests across the Atlantic and has reinforced them for several decades. On the other hand, there have been periodic, quite vocal differences between the U.S. and Europe over international affairs. How reminiscent is the current crisis period in transatlantic relations to previous ones? For those who believe in a 'Bush Gap', that the Bush administration is largely to blame for the extremity of the crisis, they hold out hope that the current era is but a momentary blip (dive?) on an otherwise solid foundation. ${ }^{61}$ Thus, once we get rid of the "skinheads of international politics [who] have taken over the White House," all will return to some sense of normalcy between the United States and Europe. $^{62}$

This paper has presented a different argument emphasizing the importance of understanding the social construction of this security community and the constituent elements underlying transatlantic relations. It is a preliminary attempt to situate the current state of the U.S.-European relationship (with apologies to Canada) in the context of the dynamics of the values and norms that create and reinforce the community's collective identity. I noted how important developments in the pre-9/11 period are to understanding current relations and attempted to highlight the extent to which there may be contrasting values and norms in the U.S. and Europe undermining this identity in the post 9/11 period. Constructivists have done well to alert us to the value of this type of approach, but generally

\footnotetext{
${ }^{60} \mathrm{See}$ http://www.washingtonpost.com/wp-dyn/content/article/2005/11/01/AR2005110101644 pf.html

${ }^{61}$ Sokolosky (2004).

${ }^{62}$ Cox (2003), p 527. The second Bush term so far seems to indicate a slight relaxing of transatlantic tensions, a la the second term of Ronald Reagan, if mainly because of domestic distractions for Bush concerning dwindling support for the Iraq war and other problems.
} 
have not outlined the processes behind how a security community can become 'deconstructed' and bonds of social identity devolve.

A next step would be more detailed empirical evidence to substantiate the argument implied in the above analysis that the transatlantic community is presently at least in a great transformative period, if not in deep crisis, due to, in large part, domestically-based changes in Europe and the U.S. Although there has been some work done on this, ${ }^{63}$ such an analysis should be complemented by more constructivist-based comparative work as done in this paper on past periods of crisis in the transatlantic but also in other security communities. ${ }^{64}$ Also interesting would be an analysis of how integrating the East European countries into both NATO and the EU will affect the transatlantic community and its evolution. In any event, a scholarly approach to the uncertain future of the transatlantic security community is not only warranted but necessary.

In the end, the transatlantic security community that exists today, and that has sustained the political and security relations between North America and Europe, should be seen as both durable yet also not ordained to continue ad infinitum. How such a community came to be developed continues to be of great interest, as it has been for many years. Only now, however, are we examining how and the extent to which such a community can falter, and we need to ask serious questions about its future.

\footnotetext{
${ }^{63}$ Risse (2003).

${ }^{64}$ See Adler and Barnett (1998).
} 


\section{References:}

Adler, E. and M. Barnett, eds. (1998), Security Communities. Cambridge, UK: Cambridge University Press.

Alterman, E. (2003) “USA Oui! Bush Non!”, The Nation, February 10.

Blinken, A. (2001) “The False Crisis Over the Atlantic”, Foreign Affairs, 80, May/June: pp 3548.

Cox, M. (2003) "Commentary: Martians and Venusians in the New World Order", International Affairs, 79 (3): pp 523-530.

Daalder, I. and J. Lindsay (2003) American Unbound: The Bush Revolution in Foreign Policy. Washington, DC: Brookings Institution Press.

Deutsch, K. (1957) Political Community and the North Atlantic Area. Princeton: Princeton University Press.

Harries, O. (2002) “Understanding America”, Centre for Independent Studies, Australia.

Hoffmann, S. (2003) “US-European Relations: Past and Future”, International Affairs, 79 (5): pp 1029-1036.

Hunter, R. (1988) "Will the United States Remain a European Power?", Survival, 30 (May/June): pp 209-227.

Jones, E. (2004) "Debating the Transatlantic Relationship: Rhetoric and Reality", International Affairs, 80 (4): pp 595-612.

Leffler, M (2003) "9/11 and the past and future of American foreign policy", International Affairs, 79 (3): pp 1045-1063.

Leffler, M. (1992) A Preponderance of Power. Stanford: Stanford University Press. 
Mastanduno, M. (1997) "Preserving the Unipolar Moment", International Security, 21 (Spring): pp 47-69.

Palmer, J. (1988) Europe Without America?. New York: Oxford University Press.

Payne, R. (2004) "Human Security and American Foreign Policy", Paper prepared for 'Human Security in the New Millennium', European Union Center, University of Missouri, Columbia, Missouri.

Peterson, J. (2002) "Europe, America and 11 September", Irish Studies in International Affairs, 13: pp 1-20.

Pierre, A., ed. (1986) A Widening Atlantic? Domestic Change and Foreign Policy. New York: Council on Foreign Relations.

Ravenal, E (1985) NATO: The Tides of Discontent. Berkeley: Institute of International Studies.

Risse-Kappen, T. (1996) "Collective Identity in a Democratic Community" in P. Katzenstein, ed. The Culture of National Security. New York: Columbia University Press.

Sjursen, H. (2004) “On the Identity of NATO”, International Affairs, 80 (4): pp 687-703.

Wallace, W. (2001) “Europe, the Necessary Partner”, Foreign Affairs, 80 (May/June): pp 1420.

Waltz, K. (1993) “The Emerging Structure of World Politics”, International Security, 18 (3): pp 47-89.

Zinmeister, K. (2003) “Old and In the Way.” Available at www.theamericanenterprise.org 